\title{
17. IgA腎症の病因解明と治療の進歩
}

\author{
順天堂大学腎臟内科学 鈴木 祐介
}

$\operatorname{IgA}$ 腎症は, 世界で最も頻度の高い原発性糸球 体腎炎である，特に，東アジアに極めて多い腎 疾患である。厚生労働省研究班によれば, 新規 に診断されるIgA腎症患者は年間約 5,000〜6,000 人で, 外来通院中 $\operatorname{IgA}$ 腎症患者は約 4 万人とされ る. 初発症状は血尿が主体で, 本邦における発 見動機は, 健康診断時の血尿が約 $70 \%$ と大半を 占める. 確定診断には腎生検による病理診断を 要するため, 尿所見異常はあるが, 腎生検未施 行の患者を考えると, この数倍, 患者は存在す ると推測される. 本疾患は, 治療未介入の場合, 約 4 割は末期腎不全に至る予後不良の疾患で, 2015 年より指定難病に認定されている. 年間約 40,959 人とされる新規透析導入患者中, $\operatorname{IgA}$ 腎症 患者は 3,000 名以上を占めている可能性がある. また, 約 33 万人の透析患者のうち, IgA腎症に 起因する透析患者は 5 7 万人はいる可能性もあ り, 年間 2,500 億円以上の医療費がIgA腎症由来 透析患者に使われていることになる．検尿シス
テムが発達している本邦といえども，いかに診 断・治療時期を逸した $\operatorname{IgA}$ 腎症患者が多いのかが 窺われる. 本疾患の病因は未だ不明ではあるが, 近年, 糖鎖修飾異常を有する異常 IgA及びその関 連免疫複合体が腎炎惹起分子であることが判明 している．また，その産生に関わる粘膜免疫異 常とその分子機序や遺伝背景等も明らかになり つつある. 責任粘膜や人種差等不明な点も多い が，欧州では，腸管作用型ステロイド薬の有効 性が示されている一方, 本邦では, 扁桃摘出 + ステロイドパルス併用療法の良好な治療成績が 相次いで報告されている.さらに, 異常 $\operatorname{IgA}$ の産 生抑制や糸球体沈着後の炎症抑制等, 異なる作 用機序を有する分子標的薬の国際治験も進行中 である。バイオマーカーを用いた健診から早期 診断に向けた試みや, 適正治療のための予後予 測モデル等多様な臨床研究も進行中で, 診断・ 治療パラダイムの変化が期待されている.

\section{8. 骨髄異形成症候群の分子病態と治療}

\section{横浜市立大学大学院医学研究科幹細胞免疫制御内科学 中島 秀明}

骨髄異形成症候群 (myelodysplastic syndromes：MDS) は, 造血幹細胞 (hematopoietic stem cell：HSC)を起源として発症する難治性造 血器腫瘍の一群である. 無効造血による慢性進 行性の血球減少と血球形態異常を特徵とし, 一 部の症例は芽球の増加から白血病に進展する. MDSは, ゲノム異常を蓄積した異常なHSCが骨 䯣中でクローン性に増殖し, 骨髄を占拠するこ とで発症する.MDSは, 疾患年齢中央值が 60〜
70 歳, 有病率は 10 万人あたり $2 \sim 3$ 人と高齢者 に多い稀な疾患であるが, 高齢化に伴い, 患者 は増加傾向にある。

MDSは, 血球減少・形態異常を呈する血球系 列の数, 末梢血・骨髄の芽球の割合, 環状鉄芽 球の有無ならびに染色体異常により, 複数のカ テゴリーに分類される. 患者の約半数に染色体 異常がみられ, その多くは $-5,-7,+8$ 等の数 的異常である。一方, MDSでは, RNA (ribonu- 